Elsevier required licence: (c) $<2017>$. This manuscript version is made available under the CC-BY-NC-ND 4.0 license http://creativecommons.org/licenses/bync-nd/4.0/ 


\section{Behavior of nitrogen removal in an aerobic sponge based moving bed biofilm reactor}

Xinbo Zhang ${ }^{\mathrm{a}, \mathrm{c}}$, Zi Song ${ }^{\mathrm{a}}$, Wenshan Guo ${ }^{\mathrm{b}, \mathrm{a}}$, Yanmin Lu ${ }^{\mathrm{a}}$, Li Qi ${ }^{\mathrm{a}}$, Haitao Wen ${ }^{\mathrm{a}, \mathrm{c}}$, Huu Hao Ngo ${ }^{\mathrm{b}, \mathrm{a}, *}$

${ }^{a}$ Department of Environmental and Municipal Engineering, Joint Research Centre for Protective Infrastructure Technology and Environmental Green Bioprocess, Tianjin Key Laboratory of Aquatic Science and Technology, Tianjin Chengjian University, Jinjing Road 26, Tianjin 300384, China.

${ }^{b}$ Centre for Technology in Water and Wastewater, School of Civil and Environmental Engineering, University of Technology Sydney, Sydney, NWS 2007, Australia

${ }^{\mathrm{c}}$ State Key Laboratory of Separation Membranes and Membrane Processes, Tianjin 300387, China

\section{Abstract}

This study aims to investigate the behavior of nitrogen removal in an aerobic sponge based moving bed biofilm reactor by evaluating nitrification and denitrification rates of sponge biocarriers from three aerobic moving bed biofilm reactors (MBBRs) with filling ratios of $10 \%$ (R-10), 20\% (R-20) and 30\% (R-30). Results showed that the highest removal efficiencies of total nitrogen in three reactors were $84.5 \%(\mathrm{R}-10), 93.6 \%(\mathrm{R}-20)$ and $95.3 \%(\mathrm{R}-30)$.

Correspondingly, simultaneous nitrification and denitrification rate (SND) was 90.9\%, 97.6\% and $100 \%$, respectively. Although R-20 had the highest attached-growth biomass (AGB) per gram of sponge compared to the other two reactors, R-30 showed the maximum ammonium oxidation rate (AOR) $\left(2.1826 \pm 0.0717 \mathrm{mg} \mathrm{NH}_{4}{ }^{+}-\mathrm{N} / \mathrm{g} \mathrm{AGB} / \mathrm{h}\right)$ and denitrification rate (DNR) (5.0852 $\left.\pm 0.0891 \mathrm{mg} \mathrm{NO}_{3}{ }^{-} \mathrm{-N} / \mathrm{g} \mathrm{AGB} / \mathrm{h}\right)$, followed by R-20 and R-10. These results indicated AOR, DNR and AGB were affected by the filling ratio under the same operation mode.

Keywords: nitrification rate, denitrification rate, moving bed biofilm reactor, sponge carrier, filling ratio

\footnotetext{
* Correspondence author: Tel: +61 29514 2745; Fax: + 61295147803
}

Email address: ngohuuhao121@gmail.com 


\section{Introduction}

With stricter regulatory and legislative effluent quality requirements and eutrophication controls in place worldwide, the removal efficiencies of organic matter as well as nutrients are required to be improved (Wang et al, 2014). Therefore, moving bed biofilm reactor (MBBR) technology as an example of efficient attached growth treatment processes, has been developed for wastewater treatment. MBBR has proven to be a very simple and efficient technology in municipal and industrial wastewater treatment (Chen et al., 2015; Bian et al., 2017; Huang et al., 2017). As noted in the study by Young et al. (2016), the MBBR system's performance depends not only on the loading rate but also the carrier type, on account of biofilm thickness, morphology and microbial population community shifts in response to the carrier type and loading rate in MBBR. Therefore the carriers in MBBR play a major role in governing microbial community within the biofilm, as well as the system operation conditions and the bioreactor performance. Different types of biofilm carriers have been introduced in MBBR technology, for instance polyethylene plastic, polyurethane sponge, biodegradable polymer, granular activated carbon, etc. (Ngo et al., 2008; Bertin et al., 2010; Chu and Wang, 2011; Wu et al., 2012; Masłon and Tomaszek, 2015 ; Li et al., 2016a).

Among these carriers, sponge is considered to be an ideal attached growth media because of its high porosity for microbial immobilization with the biomass deposition on the sponge surface and inside the sponge pores (Guo et al., 2009; Deng et al., 2016; Zhang et al., 2016). Nguyen et al. (2010) investigated the organic and nutrient removal in an up-flow sponge bioreactor with sponge cube as support media. The best performance of over $90 \%$ TOC, $95 \%$ COD, 65\% TN and 90\% TP was obtained under aerobic conditions. Chen et al. (2015) used a 
novel suspended carrier, prepared by coating a sponge on the inside and outside of a hard polyethylene ring, to obtain a quick start-up of MBBR. COD and $\mathrm{NH}_{4}{ }^{+}-\mathrm{N}$ removal rates reached $99.5 \pm 1.1$ and $93.6 \pm 2.3 \%$, much higher than those of the commercial carrier (74.9 \pm 2.7 and $40.0 \pm 1.8 \%$ ). According to the study results of Deng et al. (2016), the MBBR with sponge modified carriers improved the overall performance in terms of effluent quality and nutrient removal, compared to the MBBR with plastic carriers at HRTs of $12 \mathrm{~h}$ and $6 \mathrm{~h}$.

As the biocarrier is the key factor influencing the quantity and distribution of attached biomass and sequentially affecting nitrification and the denitrification processes in an MBBR (Zhang et al., 2013; Young et al., 2016), it is necessary to investigate the nitrogen removal behavior of the attached-growth biomass (AGB) on the biocarriers. To date, however, nitrification and denitrification rates of sponge biocarriers in an aerobic MBBR have not been examined. Thus, the objective of this study was to evaluate nitrification and denitrification rates of sponge carriers in an aerobic MBBR for understanding the behavior of nitrogen removal.

\section{Materials and methods}

\subsection{Chemicals and Materials}

The cubic-shaped polyurethane sponge $(15 \times 15 \times 15 \mathrm{~mm})$ was employed in MBBR as the biocarrier, which has a density of $28 \mathrm{~kg} / \mathrm{m}^{3}$ and cell count of 90 cells/in (90 cells per $25 \mathrm{~mm}$ ) ( Joyce Foam Pty Ltd, Australia).

1-allyl-2-thiourea (ATU) was obtained from J\&K Scientific (China), and other chemicals used in the experiments were purchased from Sangon Biotech (China). All the compounds 
were of at least analytical grade (>99\% purity).

\subsection{Synthetic wastewater}

Synthetic wastewater was used throughout the experiments to provide the influents of MBBRs. The wastewater was prepared by dissolving glucose, $\left(\mathrm{NH}_{4}\right)_{2} \mathrm{SO}_{4}, \mathrm{KH}_{2} \mathrm{PO}_{4}$ and trace elements in tap water (Zhang et al., 2016). The synthetic wastewater contained (per liter) 107.6 $\pm 5.3 \mathrm{mg}$ of total organic carbon (TOC), $15.49 \pm 1.28 \mathrm{mg}$ of $\mathrm{NH}_{4}{ }^{+}-\mathrm{N}, 2.85 \pm 0.24 \mathrm{mg}$ of total phosphorus, $0.68 \pm 0.31 \mathrm{mg}$ of $\mathrm{NO}_{3}{ }^{-} \mathrm{N}, 0.14 \pm 0.12 \mathrm{mg}$ of $\mathrm{NO}_{2}{ }^{-} \mathrm{N}$ and trace nutrients as follows (mg/L): $\mathrm{MgSO}_{4} \cdot 7 \mathrm{H}_{2} \mathrm{O}, 5.07 ; \mathrm{CaCl}_{2} \cdot 2 \mathrm{H}_{2} \mathrm{O}, 0.368 ; \mathrm{MnCl}_{2} \cdot 7 \mathrm{H}_{2} \mathrm{O}, 0.275 ; \mathrm{ZnSO}_{4} \cdot 7 \mathrm{H}_{2} \mathrm{O}$, 0.44; $\mathrm{CoCl}_{2} \cdot 6 \mathrm{H}_{2} \mathrm{O}, 0.42 ; \mathrm{CuSO}_{4} \cdot 5 \mathrm{H}_{2} \mathrm{O}, 0.391 ; \mathrm{FeCl}_{3}, 1.45 ; \mathrm{Na}_{2} \mathrm{MoO}_{4} \cdot 2 \mathrm{H}_{2} \mathrm{O}, 1.26$; and yeast extract, 30 .

\subsection{MBBR experimental set-up and operation}

Three bench-scale MBBR systems with a working volume of $12 \mathrm{~L}$ were used. Three reactors were initially filled with non-acclimatized sponge carriers at the filling ratios of $10 \%$ (R-10), 20\% (R-20) and 30\% (R-30), and were inoculated using activated sludge from a secondary sedimentation tank in a local municipal wastewater treatment plant, Tianjin, China, with the initial mixed liquor suspended solids (MLSS) of $2.8 \mathrm{~g} / \mathrm{L}$. During the start-up period of 15 days, the carriers in three reactors were acclimatized to the synthetic wastewater at the same hydraulic retention time (HRT) of $24 \mathrm{~h}$. Afterwards, the reactors were operated in continuous mode in parallel at the HRT of $12 \mathrm{~h}$ for 85 days. The dissolved oxygen (DO) concentration in R-10, R-20 and R-30 ranged from 5.0-6.5 mg/L due to the aeration that lasted throughout the entire operational period. The air flow was kept at around $0.09 \mathrm{~m}^{3} / \mathrm{h}$ in all MBBRs. Ambient temperature was around $25 \pm 1{ }^{\circ} \mathrm{C}$ and $\mathrm{pH}$ was maintained at around 7.0 by 
adjusting it with $\mathrm{NaCO}_{3}$ or $\mathrm{H}_{2} \mathrm{SO}_{4}$ in all MBBRs.

\subsection{Batch experiments}

Aerobic and anoxic batch assays were conducted to evaluate nitrification and denitrification rates of biomass attached to carriers, which were undertaken separately from three different MBBRs at designated intervals of around 15 days throughout the experimental period lasting 85 days. The measurements were conducted five times using sponge carriers in MBBRs for determining the nitrification rate (represented by ammonium oxidation rate, AOR) as well as the denitrification rate (DNR). In all batch assays samples were collected for $12 \mathrm{~h}$ at 2 hour intervals. When collection finished, the samples were filtered through $0.45 \mu \mathrm{m}$ filters and analyzed immediately.

Determination of AOR: Five replicate sponge carriers were randomly selected from each MBBR reactor, and then the attached-growth biomass of sponge carriers was collected into three $250 \mathrm{~mL}$ beakers by hand squeezing and rinsing the sponge cubes with deionized water, respectively. After being mixed using thorough stirring, $50 \mathrm{~mL}$ mixture was taken from each of the three beakers and added into three $500 \mathrm{~mL}$ Erlenmeyer flasks, respectively. In the meantime, the synthetic substrate was prepared by diluting $\mathrm{NH}_{4} \mathrm{Cl}$ and $\mathrm{KH}_{2} \mathrm{PO}_{4}$ in deionized water, and then three $300 \mathrm{~mL}$ of the synthetic substrate was added into three flasks separately. The initial concentrations of $\mathrm{NH}_{4}{ }^{+}-\mathrm{N}$ of and $\mathrm{KH}_{2} \mathrm{PO}_{4}$ were $44.36 \pm 1.36 \mathrm{mg} / \mathrm{L}$ and $50 \pm 1.87$ $\mathrm{mg} / \mathrm{L}$, respectively. $\mathrm{KH}_{2} \mathrm{PO}_{4}$ was added to avoid limited nutrient caused by phosphorus during cultivation.DO concentration for each flask was kept at around $5.5 \mathrm{mg} / \mathrm{L}$ via aeration. All the filtrated samples were analyzed for the concentration of $\mathrm{NH}_{4}{ }^{+}-\mathrm{N}$. AOR was calculated by the decrease in $\mathrm{NH}_{4}{ }^{+}-\mathrm{N}$ concentration over time and divided by the initial AGB in the reaction 
[Gong et al., 2012].

$$
\mathrm{AOR}=\frac{\left[N H_{4}^{+}-N\right]_{\text {removed }}}{T \cdot \mathrm{AGB}_{i}}
$$

Where $\left[\mathrm{NH}_{4}{ }^{+}-\mathrm{N}\right]_{\text {removed }}$ is the amount of ammonium removed in the reaction $(\mathrm{mg}), \mathrm{T}$ is the reaction time (h), and $\mathrm{AGB}_{\mathrm{i}}$ is the amount of biomass used in the reaction $(\mathrm{g})$.

Determination of DNR: Five sponge carriers randomly taken from each of the three reactors were cut up into small cubes and put into three $500 \mathrm{~mL}$ serum bottoms containing $250 \mathrm{~mL}$ deionized water that had been flushed by nitrogen. Then the attached growth biomass on the sponge carriers was detached by ultrasound. Afterwards, $50 \mathrm{~mL}$ mixture was taken from all three beakers and added into the flasks. Meanwhile, $\mathrm{NaNO}_{3}, \mathrm{KH}_{2} \mathrm{PO}_{4}$ and glucose were dissolved in deionized water as the substrate. The addition of glucose served to provide the carbon source and ensure carbon was not the limiting factor. Three $300 \mathrm{~mL}$ of the substrate was added into three flasks. The initial concentrations of $\mathrm{NO}_{3}-\mathrm{N}, \mathrm{KH}_{2} \mathrm{PO}_{4}$ and glucose were 46.23 $\pm 2.08 \mathrm{mg} / \mathrm{L}, 50 \pm 1.88 \mathrm{mg} / \mathrm{L}$ and $1000 \pm 10.27 \mathrm{mg} / \mathrm{L}$, respectively. Following this, ATU of $1 \mathrm{mg} / \mathrm{L}$ was added as the nitrification inhibitor into the synthetic substrate to eliminate the influence of nitrifiers. For the denitrification rate test, the flasks were flushed with nitrogen for $10 \mathrm{~min}$ and then tightly sealed. All flasks were placed on a shaker at $25^{\circ} \mathrm{C}$ and $120 \mathrm{rpm}$ for $12 \mathrm{~h}$. The filtrated samples were tested for $\mathrm{NO}_{3}{ }^{-} \mathrm{-N}$ concentrations. DNR was calculated by the decrease in $\mathrm{NO}_{3}{ }^{-}-\mathrm{N}$ concentration over time and divided by the initial AGB in the reaction [Gong et al., 2012].

$$
\mathrm{DNR}=\frac{\left[\mathrm{NO}_{3}^{-}-N\right]_{\text {removed }}}{T \cdot \mathrm{AGB}_{i}}
$$

Where $\left[\mathrm{NO}_{3}{ }^{-} \mathrm{N}\right]_{\text {removed }}$ is the amount of removed nitrate in the reaction $(\mathrm{mg}), \mathrm{T}$ is the reaction time (h) and $\mathrm{AGB}_{\mathrm{i}}$ is the amount of biomass used in the reaction $(\mathrm{g})$. 


\subsection{Analytical methods}

TOC was measured using a TOC analyzer (TOC-VWP, Shimadzu, Japan). $\mathrm{NH}_{4}{ }^{+}-\mathrm{N}$, $\mathrm{NO}_{2}{ }^{-}-\mathrm{N}$ and $\mathrm{NO}_{3}{ }^{-} \mathrm{N}$ were analyzed utilizing an ion chromatograph analyzer (ICS-1500, THEMORS, US). The total nitrogen (TN) was the sum of $\mathrm{NH}_{4}{ }^{+}-\mathrm{N}, \mathrm{NO}_{2}^{-}-\mathrm{N}$ and $\mathrm{NO}_{3}{ }^{-}-\mathrm{N}$. SND were calculated according to the study of Zhang et al. (2016). MLSS and mixed liquor suspended solids (MLVSS) were measured according to the Standard Methods (APHA, 2005).

\section{Results and discussion}

\subsection{MBBR performance}

Fig. 1 depicts the performance of the three MBBRs in terms of $\mathrm{NH}_{4}{ }^{+}-\mathrm{N}$, TN removal, SND

MLSS, MLVSS and AGB. As can be seen from Fig.1, the efficiencies of more than $93.6 \pm 2.6 \%$ TOC and $95.1 \pm 4.4 \% \mathrm{NH}_{4}{ }^{+}-\mathrm{N}$ on average were achieved in three MBBRs. Fig. 1 indicated that $\mathrm{R}-20$ had the highest average removal efficiencies of $95.7 \pm 1.5 \% \mathrm{TOC}$ and $97.6 \pm 2.7 \% \mathrm{NH}_{4}{ }^{+} \mathrm{N}$. Nevertheless there was no obvious difference in the treatment efficiencies of TOC and $\mathrm{NH}_{4}{ }^{+}-\mathrm{N}$ in the three reactors with different filling ratios.

It is well known TN removal mainly depends on simultaneous nitrification and denitrification (SND) performance in aerobic MBBRs. SND takes place in MBBR systems because of the oxygen concentration gradient within the biocarrier, which results in an anoxic microenvironment in the biocarrier's inner layer or the biofilm near the attached surface (Khan et al., 2011; Masłon` and Tomaszek, 2015). Although R-10, R-20 and R-30 had similar $\mathrm{NH}_{4}{ }^{+}-\mathrm{N}$ removal efficiency, R-20 and R-30 indicated better TN removal because of higher SND performance (Fig.1). The highest removal efficiency of TN in R-10, R-20 and R-30 was 
$84.5 \%, 93.6 \%$ and $95.3 \%$, respectively which correspond to the best SND performance of $90.9 \%, 97.6 \%$ and $100 \%$. In addition, $\mathrm{TN}$ in the effluent mainly consisted of $\mathrm{NH}_{4}{ }^{+}-\mathrm{N}$ and $\mathrm{NO}_{3}{ }^{-} \mathrm{N}$ with the $\mathrm{NO}_{2}{ }^{-}-\mathrm{N}$ concentration being less than $0.60 \mathrm{mg} / \mathrm{L}$. Based on the results, this gives an indication that TN removal and SND were limited by DNR. Overall, filling ratio had little influence on TOC and $\mathrm{NH}_{4}{ }^{+}-\mathrm{N}$ removal, but affected TN removal $(77.1 \pm 7.4 \%$ in $\mathrm{R}-10$ compared to $86.4 \pm 8.9 \%$ in R-30). Considering the overall treatment performance, the filling ratio of $20 \%$ was suitable for the sponge- based MBBR.

Referring to the three reactors, MLSS and MLVSS of the MBBR increased as the filling ratio also increased (Fig.1). The suspended solids in MBBR were mainly derived from the detachment of the biomass onto the carriers resulting from the hydraulic shear force and collision. Therefore larger sponge carrier volume resulted in higher MLSS and MLVSS which ranged from $0.1607 \pm 0.0451-0.4057 \pm 0.0377 \mathrm{~g} / \mathrm{L}$ and $0.1420 \pm 0.0527-0.3513 \pm 0.0837 \mathrm{~g} / \mathrm{L}$, respectively. From the comparison with the amount of biomass attached to the sponge carriers presented in Fig.1, R-10 and R-20 had a similar amount of biomass on per gram sponge (around $0.29 \mathrm{~g} \mathrm{AGB} / \mathrm{g}$ sponge), which were higher than R-30. The results demonstrated that more biomass grew in the sponge carriers in R-10 and R-20 compared to R-30. It is well known that the metabolism of the microorganisms on the carriers depended on the mass transfer in the reactor, since the substrates (e.g. oxygen, carbon and nitrogen sources) had to permeate through the carriers' inside and be transported to the microbial cells (Nicolella et al., 2000). Hence, it was concluded that the fluidization and mass transfer in R-10 and R-20 were better than in R-30 due to the lower filling ratio, which affected the growth of biomass attached to the carriers. 


\section{Fig. 1.}

\subsection{Nitrification and denitrification rates of sponge biocarriers}

\subsubsection{Nitrification rate of the sponge biocarriers in MBBRs}

Five nitrification experiments (N1, N2, N3, N4 and N5) were conducted on sponge carriers to determine the nitrification rate (represented by AOR) throughout three MBBRs' operation. AOR of sponge carriers in the three MBBRs are presented in Table 1. In terms of the nitrification rate, the highest average values of AOR were observed in R-30 carriers with 2.1826 $\pm 0.0717 \mathrm{mg} \mathrm{NH}_{4}{ }^{+}-\mathrm{N} / \mathrm{g}$ AGB /h, followed by R-20 and R-10. The values of AOR demonstrated the sponge carriers in $\mathrm{R}-30$ had the maximum amount of $\mathrm{NH}_{4}{ }^{+}-\mathrm{N}$ degradation, which indicated R-30 had more AOB within per gram AGB or higher activity of AOB compared to R-10 and R-20. While there were no obvious differences between R-10 and R-20 with reference to AOR, with the approximate $\mathrm{NH}_{4}{ }^{+}-\mathrm{N}$ degradation capacity depending on per gram biomass $\left(1.6455 \pm 0.0561 \mathrm{mg} \mathrm{NH}_{4}{ }^{+}-\mathrm{N} / \mathrm{g}\right.$ AGB $/ \mathrm{h}$ and $1.7341 \pm 0.0334 \mathrm{mg} \mathrm{NH}_{4}{ }^{+}-\mathrm{N} / \mathrm{g}$ AGB /h, respectively). Although the carrier in $\mathrm{R}-30$ exhibited the highest $\mathrm{AOR}, \mathrm{NH}_{4}{ }^{+}-\mathrm{N}$ removal efficiency of R-30 $(96.0 \pm 3.5 \%)$ was slightly lower than that of R-20 $(97.6 \pm 2.7 \%)$. It indicated that the filling ratio reached up to $30 \%$, while the $\mathrm{NH}_{4}{ }^{+}-\mathrm{N}$ treatment performance of MBBR did not correspondingly improve when the filling ratio increased. Furthermore, the porous carriers has the excellent porous structure, which can promote biofilm accumulation by providing a large surface area and protect the biofilm from fluid shearing and collision by providing sheltered anchoring points. However, the porous has the drawback of the low mass transfer efficiency (Chen et al., 2015). Consequently, the sponge biocarriers possess the above characters as one of the porous carriers. For this reason, this suggested the reduction in the 
substrates being transferred to the biomass in the biocarriers in MBBR was caused by an increase in the filling ratio utilizing the same oxygen supply. In other words, volume of carriers (i.e. higher filling ratio) has an adverse influence to the circulation of the sponge carriers in the reactor under the same DO supply, which made it difficult for the mass to transfer deep inside the porous sponge carrier and sequentially reduced the mass transfer efficiency.

\section{Table 1.}

3.2.2 Denitrification rate of the sponge biocarriers in MBBRs

Five experiments (N1, N2, N3, N4 and N5) were conducted at around 15-day intervals for every MBBR to determine the denitrification rate of biocarriers. DNR of the sponge carriers in three MBBRs are summarized in Table 2. Based on the results shown in Table 2, the values of DNR followed the order: R-30 > R-20 > R-10, increasing with the filling ratio. This behavior was consistent with TN removal performance of three reactors. The sponge carriers in R-30 exhibited the maximum DNR with 5.0852 $\pm 0.0891 \mathrm{mg} \mathrm{NO}_{3}{ }^{-} \mathrm{N} / \mathrm{g} \mathrm{AGB} / \mathrm{h}$. Therefore, this could account for R-30's better TN removal and SND performance compared to the other two reactors besides the filling ratio, in spite of minimum AGB per gram sponge among three reactors. The denitrification capacity of the carriers in R-10 was close to R-20 (Table 2),

hence the difference in the R-10 and R-20 TN removal efficiencies was caused by the total amount of the attached biomass on the carriers in the reactor varying from the filling ratio.

The sponge carrier's volume (3.6 L under 30\% filling ratio) multiplied by the sponge density $\left(28 \mathrm{~kg} / \mathrm{m}^{3}\right)$, the total mass of sponge in the R-30 was $100.8 \mathrm{~g}$. Combined with the AGB value (0.2526 $\pm 0.0838 \mathrm{~g} \mathrm{AGB/g}$ sponge) and DNR of R-30, all TN in the influent can theoretically 
be removed by the treatment. However, $86.4 \pm 8.9 \%$ TN removal of R-30 was achieved and this was approximately $1 \%$ higher than that of R-20, despite the fact that both reactors were being operated under the same conditions. Hence, the filling ratio influenced the mass transfer of nutrients and substrates to the microbial community embedded in the sponge biofilm (Young et al., 2016). In contrast, the larger filling ratio reduced the substrates' transfer in R-30. Moreover, the substrates' diffusion in the biofilm depended on flow velocities across the biofilm. Any increases in flow velocity resulted in larger localized concentration gradients in the biofilm and faster rates of diffusion through the biofilm (Li et al., 2016b). Furthermore the flow velocity in aerated MBBR is linked to the aeration flow. Consequently, the aeration supply should be adjusted by the filling ratio variation of the aerated MBBR for better mass transfer. The aeration flow not only provides dissolved oxygen, but also enables biocarriers to move in the MBBR system. Also, DO and velocity of biocarrier movement do wield an influence on the performance of the MBBR. Nevertheless, both the filling ratio and air flow rate involve the costs for operating the MBBR system. Therefore the results proved again that the optimum filling ratio of sponge-based MBBR was $20 \%$.

\section{Table 2.}

\section{Conclusions}

Nitrogen removal's behavior in a sponge based MBBR was successfully investigated via DNR, AOR and SND performance. Interestingly, R-20 could lead to highest AGB while the values of AOR and DNR as well as TN removal and SND followed the order: R-30 > R-20 > R-10. The carriers in R-30 exhibited maximum AOR and DNR but lower AGB. 


\section{Acknowledgements}

This study was supported by Tianjin Municipal Science and Technology Commission Project (16JCTPJC51200, 16YFXTSF00390), Tianjin "131" Innovative Talents Training Project and National Natural Science Foundation (No. 51308373 and No. 51378338). The research collaboration between Tianjin Chengjian University and University of Technology Sydney is very grateful.

\section{References}

1. APHA, AWWA, WEF, 2005. Standard Methods for the Examination of Water and Wastewater, 20th ed. American Public Health Association, Washington, DC.

2. Bertin, L., Lampis, S., Todaro, D., Scoma, A., Vallini, G., Marchetti, L., Majone, M., Fava, F., 2010. Anaerobic acidogenic digestion of olive mill wastewaters in biofilm reactors packed with ceramic filters or granular activated carbon. Water Res. 44, 4537-4549.

3. Bian, W., Zhang, S., Zhang, Y., Li, W., Kan, R., Wang, W., Zheng, Z., Li, J., 2017. Achieving Nitritation in a Continuous Moving Bed Biofilm Reactor at Different Temperatures through Ratio Control. Bioresour. Technol. 226, 73-79.

4. Chen, X., Kong, L., Wang, X., Tian, S., Xiong, Y., 2015. Accelerated start-up of moving bed biofilm reactor by using a novel suspended carrier with porous surface. Bioprocess Biosyst. Eng. 38, 273-285.

5. Chu, L., Wang, J., 2011. Nitrogen removal using biodegradable polymers as carbon source and biofilm carriers in a moving bed biofilm reactor. Chem. Eng. J. 170, 220-225.

6. Deng, L, Guo, W., Ngo, H. H., Zhang, X., Wang, X., Zhang, Q., Chen, R., 2016. New functional 
biocarriers for enhancing the performance of a hybrid moving bed biofilm reactor-membrane bioreactor system. Bioresour. Technol. 208, 87-93.

7. Guo, W., Ngo, H.H., Palmer, C.G., Xing, W., Hu, A.Y., Listowski, A., 2009. Roles of sponge sizes and membrane types in a single stage sponge-submerged membrane bioreactor for improving nutrient removal from wastewater for reuse. Desalination 249 , $672-676$.

8. Huang, C., Shi, Y., Xue, J., Zhang, Y., El-Din, M.G., Liu, Y., 2017. Comparison of biomass from integrated fixed-film activated sludge (IFAS), moving bed biofilm reactor (MBBR) and membrane bioreactor (MBR) treating recalcitrant organics: Importance of attached biomass. J. Hazard. Mater. 326, 120-129.

9. Khan, J.S., Ilyas, S., Javid, S., Visvanathan, C, Jegatheesan, V., 2011. Performance of suspended and attached growth MBR systems in treating high strength synthetic wastewater. Bioresour. Technol. 102, 5331-5336.

10. Li, C., Felz, S., Wagner, M., Lackner, S., Horn, H., 2016a. Investigating biofilm structure developing on carriers from lab-scale moving bed biofilm reactors based on light microscopy and optical coherence tomography. Biotechnol. Bioeng. 200(5), 128-136.

11. Li, C., Wagner, M., Lackner, S., Horn, H., 2016b. Assessing the influence of biofilm surface roughness on mass transfer by combining optical coherence tomography and two-dimensional modeling. Biotechnol. Bioeng. 113(5), 989-1000.

12. Masłon', A., Tomaszek, J. A., 2015. A study on the use of the BioBall as a biofilm carrier in a sequencing batch reactor. Bioresour. Technol. 196, 577-585.

13. Ngo, H.H., Guo, W.S., Xing, W., 2008. Evaluation of a novel sponge-submerged 
membrane bioreactor for sustainable water reclamation. Bioresour. Technol. 99, 2429-2435.

14. Nguyen, T. T., Ngo, H. H., Guo, W., Johnston, A., Listowski, A., 2010. Effects of sponge size and type on the performance of an up-flow sponge bioreactor in primary treated sewage effluent treatment. Bioresour. Technol. 101, 1416-1420.

15. Nicolella, C., Loosdrecht, M.C.M., Heijnen, J.J. 2000. Wastewater treatment with particulate biofilm reactors. J. Biotechnol. 8, 1-33.

16. Wang, J., Zheng, Y., Jia, H., Zhang, H. 2014. Bioelectricity generation in an integrated system combining microbial fuel cell and tubular membrane reactor: Effects of operation parameters performing a microbial fuel cell-based biosensor for tubular membrane bioreactor. Bioresour. Technol. 170, 483-490.

17. Wu, W., Yang, F., Yang, L., 2012. Biological denitrification with a novel biodegradable polymer as carbon source and biofilm carrier. Bioresour. Technol. 118, 136-140.

18. Young, B., Banihashemi, B., Forrest, D., Kennedy, K., Stintzi, A., Delatolla, R., 2016. Meso and micro-scale response of post carbon removal nitrifying MBBR biofilm across carrier type and loading. Water Res. 91, 235-243.

19. Zhang, S., Wang, Y., He, W., Xing, M., Wu, M., Yang, J., Gao, Na., Sheng, G., Yin, D., Liu, S., 2013. Linking nitrifying biofilm characteristics and nitrification performance in moving-bed biofilm reactors for polluted raw water pretreatment. Bioresour. Technol. 146, 416-425.

20. Zhang, X., Chen, X., Zhang, C., Wen, H., Guo, W., Ngo, H. H., 2016. Effect of filling fraction on the performance of sponge-based moving bed biofilm reactor. Bioresour. 
Technol. 219, 762-767. 


\section{Figures}

\section{Figure captions:}

Fig.1. TOC, $\mathrm{NH}_{4}{ }^{+} \mathrm{-N}$, TN removal efficiencies, SND, MLSS, MLVSS and AGB in three MBBRs with different filling ratios (mean data). AGBa: the amount of AGB per gram of sponge. 


\section{ACCEPTED MANUSCRIPT}

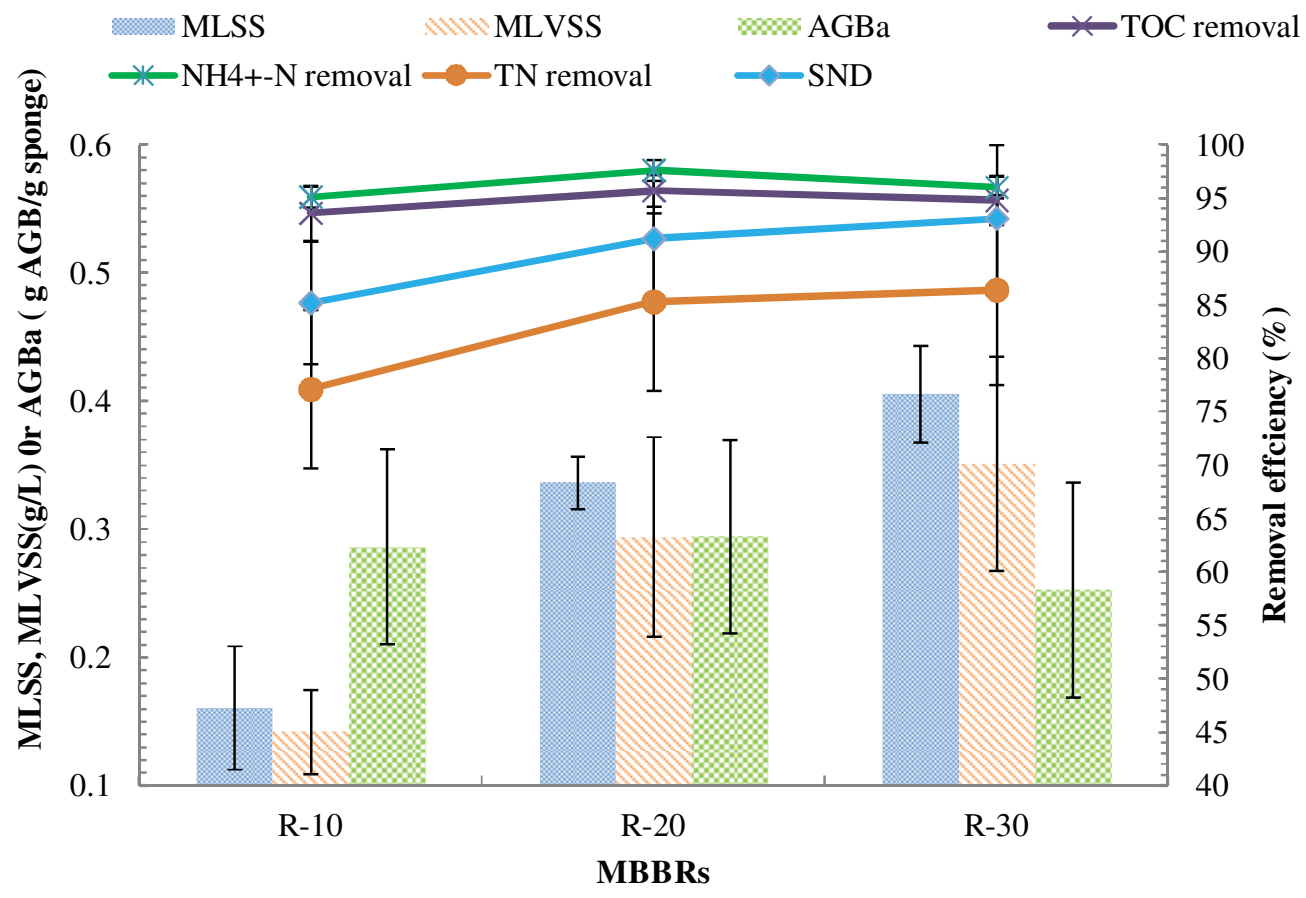

Fig.1. 


\section{Tables}

\section{Table captions:}

Table 1. The ammonium oxidation performance of sponge biocarriers in aerobic batch assays

Table 2. The denitrification performance of sponge biocarriers in anoxic batch assays 


\section{ACCEPTED MANUSCRIPT}

Table 1. The ammonium oxidation performance of sponge biocarriers in aerobic batch assays

\begin{tabular}{cccccccc}
\hline Experiment & & $\mathrm{N} 1$ & $\mathrm{~N} 2$ & $\mathrm{~N} 3$ & $\mathrm{~N} 4$ & $\mathrm{~N} 5$ & $\mathrm{AVE}$ \\
\hline \multirow{2}{*}{$\mathrm{AOR}$} & $\mathrm{R}-10$ & $1.6443 \pm 0.0216$ & $1.5837 \pm 0.0401$ & $1.6260 \pm 0.0445$ & $1.6231 \pm 0.0302$ & $1.7505 \pm 0.0543$ & $1.6455 \pm 0.0561$ \\
$\left(\mathrm{mg} \mathrm{NH}_{4}{ }^{+}-\mathrm{N} / \mathrm{g} \mathrm{AGB} / \mathrm{h}\right)$ & $\mathrm{R}-20$ & $1.7300 \pm 0.0223$ & $1.6950 \pm 0.0533$ & $1.7711 \pm 0.0328$ & $1.7010 \pm 0.0201$ & $1.7737 \pm 0.0325$ & $1.7341 \pm 0.0334$ \\
& $\mathrm{R}-30$ & $2.1011 \pm 0.0304$ & $2.0981 \pm 0.0607$ & $2.1961 \pm 0.0506$ & $2.2664 \pm 0.0241$ & $2.2513 \pm 0.0518$ & $2.1826 \pm 0.0717$ \\
\hline
\end{tabular}

AOR: obtained by dividing the amount of $\mathrm{NH}_{4}{ }^{+} \mathrm{N}$ degradation with the reaction time by the AGB;

AVE: the mean value with standard deviation. 
Table 2. The denitrification performance of sponge biocarriers in anoxic batch assays

\begin{tabular}{|c|c|c|c|c|c|c|}
\hline Experiments & & DN1 & DN2 & DN3 & DN4 & DN5 \\
\hline \multirow{3}{*}{$\begin{array}{c}\mathrm{DNR} \\
\left(\mathrm{mg} \mathrm{NO}_{3}{ }^{-}-\mathrm{N} / \mathrm{g} \mathrm{AGB} / \mathrm{h}\right)\end{array}$} & $\mathrm{R}-10$ & $4.2677 \pm 0.0554$ & $4.0441 \pm 0.0940$ & $4.0194 \pm 0.1001$ & $4.0870 \pm 0.1205$ & $4.1690 \pm 0.1124$ \\
\hline & $\mathrm{R}-20$ & $4.5546 \pm 0.0521$ & $4.7251 \pm 0.0777$ & $4.4987 \pm 0.0920$ & $4.5108 \pm 0.1159$ & $4.6458 \pm 0.1008$ \\
\hline & $\mathrm{R}-30$ & $4.9146 \pm 0.0684$ & $5.0924 \pm 0.0646$ & $5.1573 \pm 0.0508$ & $5.1067 \pm 0.0649$ & $5.1548 \pm 0.0742$ \\
\hline
\end{tabular}

DNR: obtained by dividing the amount of $\mathrm{NO}_{3}{ }^{-} \mathrm{N}$ degradation with the reaction time by the AGB;

AVE: the mean value with standard deviation. 


\section{Highlights}

- The AOR and DNR of the biocarriers increased with increasing filling ratio.

- There was no obvious difference in AOR and DNR between R-10 and R-20.

- The optimum filling ratio of sponge-based MBBR was $20 \%$ with highest AGB and TN removal.

- The AGB amount of the carriers varied in MBBRs with different filling ratios. 